\title{
Representasi Kerinduan dalam Lagu Umm Kulthūm Qișsat Hubb Karya Aḥmad Rāmī: Analisis Semiotik Charles Morris
}

\author{
Roisah Fathiyatur Rohmah* \\ Universitas Islam Negeri (UIN) Sunan Kalijaga, Yogyakarta, Indonesia
}

\section{Representation of Longing in the Umm Kulthūm's Song Qișsat Hubb \\ Created by Aḥmad Rāmī: Charles Morris' Semiotic Analysis}

\section{E-Mail Address}

Pingpooping97@gmail.com

${ }^{*}$ Corresponding Author

\section{Keywords}

Semiotic;

the longing of a man;

qișat bubb

\begin{abstract}
The purpose of this research is to reveal the representation of a male character's longing for his lover in the song Qișat Hubb, a song full of emotion. The song was sung by Umm Kulthum, a famous singer from Egypt who has a big influence in the Arab world. The song Qissat Hubb was composed by an Egyptian writer named Ahamd Rāmī. In the song Qissat Hubb, some signs have a deeper meaning. The study of meaning in this study uses Charles Morris's theory of semiotics, which is divided into three, namely syntactic meaning, semantic, and pragmatic meaning. This study used a descriptive-analytic method by describing the data on the object of research, then continued with the analysis. The results of this study indicate that the syntactic meaning in the song Qișat Hubb is the sadness of a man because he reminisces with his late lover. The semantic meaning of this song is the confusion of a man who is abandoned by his lover. Meanwhile, the pragmatic meaning is the longing of a man for his lover which causes suffering and almost drives him crazy.
\end{abstract}

\section{Pendahuluan}

Karya sastra merupakan struktur yang memiliki makna. Hal ini menunjukkan bahwa karya sastra merupakan sistem tanda yang mempunyai makna yang disampaikan melalui bahasa. Bahasa sebagai medium karya sastra merupakan sistem semiotik atau tanda yang memiliki arti. Sebelum bahasa digunakan dalam karya sastra, bahasa tersebut sudah memiliki arti yang ditentukan oleh konvensi masyarakat (Pradopo, 1987). Karya sastra merupakan hasil inspirasi maupun pengalaman pengarang yang dituangkan menjadi sebuah tulisan. Dalam menciptakan karya sastra, sastrawan tidak hanya mementingkan keindahan, namun juga mampu menyampaikan makna agar pembaca ikut menikmati karya sastra tersebut.

Lagu merupakan bagian dari karya sastra jenis puisi. Menurut Siswantoro (2010), puisi berbeda dengan novel, drama, maupun cerita pendek. Puisi ditandai dengan sedikit kata, tetapi mengungkapkan makna yang banyak. Lagu yang ditulis oleh penyair merupakan perwujudan 
ungkapan sikap, perasaan, dan aspirasi terhadap persitiwa. Lagu adalah jenis puisi tipe lirik dan erupakan ungkapan perasaan dari seorang penyair yang dicurahkan melalui tulisan. Tentunya dalam sebuah lagu terdapat tanda-tanda yang disampaikan melalui bahasa serta memiliki makna. Makna dalam sebuah lagu belum tentu dipahami oleh orang yang membaca maupun orang yang mendengarkan lagu tersebut.

Pengkajian mengenai tanda mendapat perhatian oleh Charles William Morris (1901-1979), seorang murid Ferdinand de Saussure yang berkebangsaan Amerika pada abad ke-20. Ia merupakan tokoh besar semiotik yang berpengaruh terhadap perkembangan sejarah semiotik pada tahun 19301940 (Nöth, 2006). Semiotik menurut Morris adalah ilmu yang memperlajari tentang perilaku (science of behavior). Dengan begitu, objek penelitian semiotik adalah sikap yang dapat dipahami dan diamati sebagai respon makhluk hidup terhadap rangsangan. Dengan kata lain, objek dari penelitian semiotik Morris adalah sikap suatu tanda (Trabaut, 1996).

Proses semiosis menurut Morris melibatkan tiga faktor, yaitu tindakan yang bertindak sebagai tanda, tanda yang diacu, dan efek terhadap interpreter berdasarkan tanda tersebut. Tiga komponen dalam semiosis tersebut disebut dengan sign vebicle (alat tanda), designatum dan interpretan. Sign vehicle adalah which act as a sign, designatum yaitu which the sign refers to, dan interpretan adalah that effect on some interpreter in virtue of which the thing in question is a sign to that. Dalam membagi tanda, Morris membagi semiotik menjadi tiga lapis, yaitu sintaksis, semantik dan pragmatik. Makna sintaktis merupakan makna yang diperoleh antartanda dengan tanda (sign vebicle) lain. Makna semantik merupakan makna yang diperoleh dari relasi tanda dengan arti, konsep atau ide mengenai tanda tersebut (designatum). Sementara itu, makna pragmatik merupakan makna yang diperoleh antara tanda dengan interpreternya (Nöth, 1990).

Menurut Carnap, dalam menganalisis bahasa tidak selalu menaruh perhatian terhadap ujarannya, namun perlu berurusan dengan pengujar dan acuannya. Oleh karena itu, perlu adanya penelitian dalam ranah tiga bahasa, yaitu sintaksis, semantik, dan pragmatik. Apabila dalam penelitian yang menjadi acuan adalah ujaran, maka itu berada dalam ranah sintaksis. Namun, apabila penelitian beracuan pada pengujar atau pemakai bahasa, hal itu masuk dalam ranah pragmatik. Sementara itu, ketika penelitian hanya menganalisis ujaran dan acuannya, maka ia masuk dalam ranah semantik (Zaimar \& Harahap, 2014). Di sisi lain, Petrilli (2004) mengatakan bahwa konsep pragmatis Morris tidak hanya fokus pada tanda, namun juga fokus pada nilai. Penggunaan teori Charles Morris ini cocok untuk menganalisis sebuah lagu agar makna menjadi sempurna dikarenakan melewati tiga tahapan tataran kebahasaan.

Umm Kulthūm merupakan salah satu penyanyi legendaris Mesir yang populer pada abad ke-20. Ia sangat dikagumi oleh para pendengar musiknya karena keindahan suaranya. Tidak jarang masyarakat Mesir, bahkan bangsa Arab seluruhnya, membanggakan Umm Kulthūm. Oleh karenanya, ia diberi julukan star of the East (kawkab al-sharq), bintang dari Timur. Umm Kulthūm juga meninggalkan warisan budaya Arab Mesir, khususnya dalam kekhasan dan warna musik padang pasir (Manshur, 2011). Seorang kritikus film dan music Mesir, Ṭāriq al-Shinnāwī, mengatakan bahwa Umm Kulthūm sudah melampai batas geografis, karena ia sudah populer di belahan mana pun. Umm Kulthūm bukan hanya sebagai ikon dari negara Mesir, namun sudah menjadi the voice of $\operatorname{Arab}$ (Kiram, 2019).

Ada banyak lagu yang dibawakan oleh Umm Kulthūm, baik yang diciptakan oleh dirinya sendiri, maupun orang lain. Salah satu pencipta lagu dari Umm Kulthūm adalah Aḥmad Rāmī. Ia 
Representasi Kerinduan dalam Lagu Umm Kulthūm Qișsat Hubb Karya Aḥmad Rāmī:

Analisis Semiotik Charles Morris

merupakan seorang sastrawan Mesir, penulis dan penerjemah puisi, dan juga penulis lagu. Terdapat 137 lagu yang dinyanyikan oleh Ummi Kultsum adalah buah karya Aḥmad Rāmī (Danielson, 1997). Aḥmad Rāmī merupakan sastrawan Mesir yang memperkenalkan diwan baru dalam syairnya, yaitu cinta dan emosional. Ia memberikan kesempatan kepada penyair Arab untuk mengungkapkan perasaan yang mendalam dan penuh emosi dari perspektif laki-laki. Oleh karenanya, Daliro, seorang orientalis Inggris, menjuluki Aḥmad Rāmī dengan sebutan love of poets. Seorang penyair dan kritikus sastra terkenal, Taimour juga mengapresiasi peran Rāmī dalam mengolah dan membangun dialek dalam bahasa Arab (“Ahmed Rami,” 2009).

Peranan Aḥmad Rāmī dalam pembaharuan syair-syair Arab perlu dikaji lebih lanjut, khususnya lagu yang dinyanyikan oleh Umm Kulthūm, karena memiliki dampak yang besar dalam proses dialog antara penyair dengan masyarakat. Salah satu lagu ciptaan Aḥmad Rāmī yang menggugah emosi adalah Qișat Hubb. Lagu Qisssat Hubb ini menceritakan tentang kerinduan seorang laki-laki kepada kekasihnya penuh dengan emosional. Lagu tersebut banyak menggunakan kata كيف yang berarti "bagaimana”, yang seolah-olah bertanya-tanya mengenai kekasihnya. Melalui lagu ini Aḥmad Rāmī menceritakan tentang kerinduan seorang laki-laki dengan kekasihnya, namun ia tidak akan bisa bertemu. Kata-kata yang digunakan dalam lagu ini tidak menunjukkan sebuah reaksi dari tokoh dalam lagu tersebut, juga tidak menunjukkan makna secara langsung mengenai maksud dan tujuan dari lagu tersebut.

Sehubungan dengan topik mengenai lagu Qișsat Hubb, karenanya perlu ada pembahasan mengenai tanda-tanda dalam lagu tersebut yang membahas tentang kenangan seorang laki-laki bersama kekasihnya sehingga para pendengar lagu dapat menikmati dan mengahayati apa makna yang terkandung dalam lagu tersebut. Dalam penelitian ini akan membahas mengenai gambaran kerinduan seorang kekasih yang digambarkan dalam lagu Qissat Hubb dengan menggunakan teori semiotik Charles Morris dengan melihat dari segi makna sintaksis, semantic, dan pragmatik. Namun sebelumnya, penelitian dengan objek material lagu Qișat Hubb pernah dilakukan oleh Tara Thuraya (2009) dengan judul "Lagu-lagu Ummi Kulsum Karya Ahmad Muhammad Rami: Analisis Struktur Teks dan Isi”. Ada tiga lagu yang diteliti dalam penelitian ini, salah satunya adalah lagu Qissat Hubb. Penelitian ini membahas mengenai struktur dan isi yang terdapat dalam lagu Qișsat Hubb. Hasil dari penelitian ini menunjukkan bahwa lagu tersebut memiliki unsur bunyi yang cukup kental. Jika ditinjau dari ilmu badī', lagu tersebut mengandung al-mubassināt al-lafžìyah yang memberikan sentuhan keindahan bunyi tersendiri serta memiliki makna yang mendalam, namun diungkapkan secara sederhana.

Penelitian dengan menggunakan semiotik model Charles Morris, dilakukan oleh Nidda Amirotul Qoriah (2018) dengan judul "Qaṣīdat al-Ṭalāsim li-Îlyā Abū Māọī: Dirāsah Tahlīlīyah Sīmāīyah li-Charles Morris". Penelitian tersebut bertujuan untuk mengungkap tanda-tanda yang ada dalam puisi al-Ṭalāsim karya Īlyā Abū Māḍī yang didasarkan pada tiga aspek kebahasaan, yaitu aspek sintaksis, semantik dan pragmatik. Hasil dari penelitian ini menunjukkan bahwa aspek sintaksis puisi tersebut memiliki arti keterpaksaan, dan dari aspek semantik puisi tersebut adalah watak eksistensi manusia di dunia yang ingin selalu bertanya. Sementara itu, aspek pragmatik memiliki arti ketidaktahuan. Kemudian, penelitian Indah Lestari dkk (2020) yang berjudul "Morris' Semiotic in Religion Perception and Conception in Gane of Polinaki Traditional Wedding Ritual in Kulawi Ethnic”. Penelitian ini membahas konsep agama dalam Gane, yaitu pidato ritual yang masih 
dipraktikkan oleh etnis Kulawi di Kabupaten Sigi, Sulawesi Tengah. Dari segi sintaksis, Gane merupakan sebuah teks sastra yang memiliki keunikan dari segi struktur, fungsi dan makna. Dari segi semantik, Gane memiliki makna puitis, sedangkan dari segi pragmatik, Gane memberikan pengaruh terhadap konsepsi dan persepsi agama.

Berdasarkan penelitian-penelitian di atas, belum ada penelitian dengan menggunakan objek material dan objek formal yang sama. Oleh karena itu, penelitian dengan judul "Representasi Kerinduan dalam Lagu Umm Kulthūm Qiṣsat Hubb Karya Aḥmad Rāmī: Analisis Semiotik Charles Morris" menjadi layak untuk diteliti. Fokus kajiannya adalah mengidentifikasi tanda yang memiliki arti mendalam dalam lagu Qișat Hubb. Dalam teori semiotika Charles Morris, makna tersebut dibagi menjadi tiga macam, yaitu makna sintaksis, makna semantik, dan makna pragmatis.

\section{Metode Penelitian}

Penelitian ini bersifat deskriptif kualitatif dengan kajian pustaka (library research). Metode ini dilakukan dengan cara mendiskripsikan data-data fakta pada objek penelitian kemudian disusul dengan analisis. Data dari penelitian ini adalah lagu Qiṣ̦at Hubb karya Aḥmad Rāmī, dan ditunjang dengan berbagai data yang relevan dengan penelitian ini. Teknik pengumpulan data dilakukan dengan teknik dokumentasi, yaitu mengumpulkan informasi dari berbagai dokumen baik buku, majalah, maupun artikel jurnal. Adapun metode analisis data yang digunakan adalah metode deskriptif analitis, yaitu penelitian dengan cara menyajikan fakta lalu dianalisis secara sistematis. Tanda-tanda dalam lagu Qișat Hubb dikumpulkan, kemudian dikategorikan ke dalam kalimat yang sering muncul dalam lagu (makna sintaksis), tanda-tanda yang memiliki makna konotasi dan denotasi (makna semantik), dan tanda yang berupa isotopi dan motif (makna pragmatik).

\section{Hasil Penelitian dan Pembahasan}

A. Lirik Lagu Qișsat Hubb Karya Aḥmad Rāmī

$$
\begin{aligned}
& \text { ذكريات عبرت أفق خيالي بارقا يلمع في جنح الليالي } \\
& \text { نبهت قلبي من غفوته جلت لي ستر أيامي الخوالي } \\
& \text { كيف أنساها وقلبي لم يزل يسكن جنبي } \\
& \text { إنها قصة حبي } \\
& \text { ذكريات داعبت فكري وظني لست أدري ايها أقرب مني } \\
& \text { هي في سمعي على طول المدى نغم ينساب في لحن أغن } \\
& \text { بين شدو وحنين وبكاء وأنين } \\
& \text { كيف أنساها وسمعي لم يذكر دمعين وأي وائين } \\
& \text { وأنا أبكي مع اللحن الحزين } \\
& \text { كان فجرا باسما في مقلتيها يوم أشرقت من الغيب عليا } \\
& \text { أنست روحي إلى طلعته واجتلت زهر الهوى غضاً نديا } \\
& \text { فسقيناه ودادا ورعيناه وفاء } \\
& \text { ثم همنا فيه شوقا وقطفناه لقاء }
\end{aligned}
$$




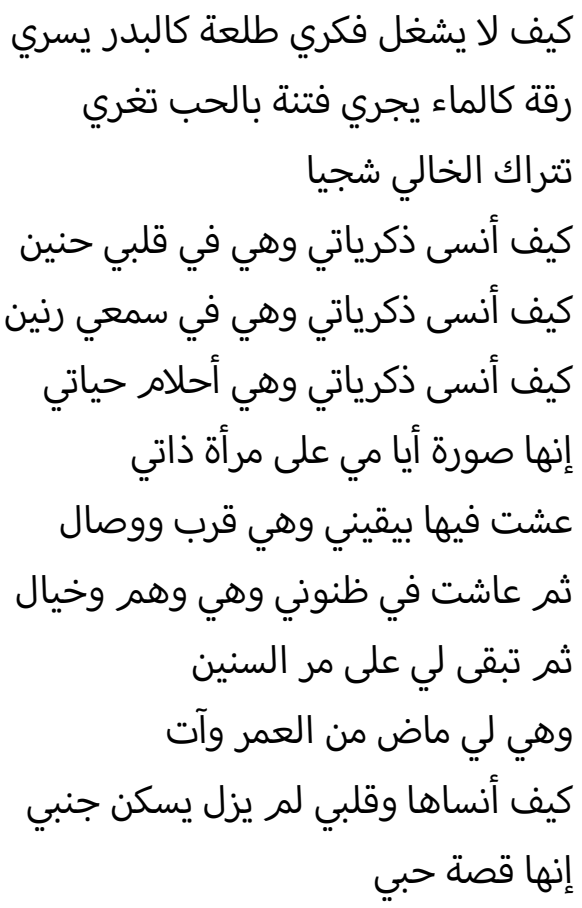

Kenangan berlalu membuka khayalan, cahaya yang bersinar di kegelapan malamku

Membangunkan hatiku dari tidur dan menutupiku pada kelambu hari tuaku

Bagaimana aku lupa, bisikan hatiku masih membekas di dalamnya

Ini kisah cintaku

Kenangan bertentangan dalam pikiran dan perasaan, aku tidak tahu yang mana yang lebih dekat dengan ku

Dia selalu terngiang sepanjang waktu, senandung harmoni dalam melodi yang merdu

Melagukan kerinduan dan kegelisahan

Bagaimana aku melupakan sedangkan aku masih mendengar dan mengingat air mataku

Aku menangis dengan nada sendu

Fajar lalai dalam menyinari hati yang tidak diketahui

Jiwaku lupa pada kuncup bunga-bunga mawar muncul merekah

Untuk menyirami cinta dan menjaga kesetiaan

Lalu penderitaan karena di dalamnya kerinduan dan kita menggoreskan pertemuan

Bagaimana pikiranku tidak sibuk melihat bulan purnama menyingsing

Kelembutan seperti air mengalir hasutan dengan cinta menggoda

Jarak ini membuatku berduka

Bagaimana aku dapat melupakan kenanganku dan dia di hatiku rindu

Bagaimana aku dapat melupakan kenanganku dan dia dalam suara berpadu

Bagaimana aku dapat melupakan kenanganku dan dia mimpi hidupku

Ini adalah gambaran hari-hariku bercermin sendiri

Hidup di dalamnya dengan keyakinanku dan dia terpaut di dekatku

Lalu aku hidup dalam bayang-bayang dan dia bayangan nyata

Lalu bertahun-tahun kemudian

Dan dia di masa lalu dan masa depanku

Bagaimana aku melupakannya dan dia masih di hatiku

Inilah kisah cintaku 


\section{B. Makna Sintaksis}

Makna sintaksis dalam semiotika Charles Morris adalah makna yang diperoleh antartanda dengan tanda (sign vebicle) lain di mana hubungan antartanda tersebut memberikan makna (Nöth, 1990). Hal ini ditandai dengan kalimat yang sering muncul dalam lagu tersebut. Lagu Qișsat Hubb berisi tentang kenangan tokoh aku (laki-laki) yang merindukan kekasihnya. Pada awal bait diungkapkan dengan lirik ذكريات عبرت أفق خيالي بارقا يلمع في جنح الليالي (kenangan berlalu membuka khayalan, cahaya yang bersinar di kegelapan malamku) yang berarti bahwa kenangan mengenai kekasihnya sudah berlalu, namun tiba-tiba 'Aku' teringat kenangan tersebut. Kejadian tersebut terjadi pada malam hari saat laki-laki tersebut tidur lalu terbangun. Dalam lagu ini disebutkan kata كيف sebanyak tujuh kali. Hal ini menandakan bahwa tokoh 'Aku' tersebut bertanya-tanya tentang kenangan bersama kekasihnya. Kata أنسى disandingkan dengan kata memiliki arti bahwa 'Aku' tidak bisa melupakan kekasihnya. Begitu juga dengan kata كيف pada lirik selanjutnya.

$$
\text { كيف أنساها وقلبي لم يزل يسكن جنبي }
$$

Bagaimana aku lupa, bisikan hatiku masih membekas di dalamnya

$$
\text { كيف أنساها وسمعي لم يذكر دمعي }
$$

Bagaimana aku melupakan sedangkan aku masih mendengar dan mengingat air mataku

$$
\text { كيف أنسى ذكرياتي وهي في قلبي حنين }
$$

Bagaimana aku dapat melupakan kenanganku dan dia di hatiku rindu

$$
\text { كيف أنسى ذكرياتي وهي في سمعي رنين }
$$

Bagaimana aku dapat melupakan kenanganku dan dia dalam suara berpadu

$$
\text { كيف أنسى ذكرياتي وهي أحلام حياتي }
$$

Bagaimana aku dapat melupakan kenanganku dan dia mimpi hidupku

$$
\text { كيف أنساها وقلبي لم يزل يسكن جنبي }
$$

Bagaimana aku melupakannya dan dia masih di hatiku

كيف لا يشغل فكري طلعة yaitu أنسى Terdapat satu kata yang tidak disandingkan dengan kata كيف كالبدر يسري (bagaimana pikiranku tidak sibuk melihat bulan purnama menyingsing) juga memiliki arti bertanya-tanya dan menceritakan tentang dirinya yang sibuk melihat bulan purnama. Penggunaan kata كيف memberi tanda seolah-olah menyalahkan kepada kekasihnya.

Dalam lagu ini terdapat kesedihan yang diceritakan oleh tokoh 'Aku' seperti دمعي (air mata), أبكي (aku menangis), dan شجيا (berduka). Kata-kata tersebut menunjukkan bahwa tokoh 'Aku' sedang merasakan kesedihan. Kesedihan tersebut disebabkan rasa rindu terhadap kekasihnya. Hal ini dijelaskan dalam lirik yang diungkapkan oleh tokoh 'Aku' seperti وقلبي لم يزل يسكن جنبي (bisikan hatiku masih membekas didalamnya), هي في سمعي على طول المدى (dia selalu terngiang sepanjang waktu), بين شدو وحنين وبكاء وأنين (melagukan kerinduan dan kegelisahan) dan ثمي في (همئ فيه شوقي 
(penderitaan karena di dalamnya kerinduan). Tokoh 'Aku' tidak bisa melupakan kekasihnya karena masih ada rasa rindu di dalam hatinya dan membuatnya sedih sepanjang waktu.

Dalam lirik Qișsat Hubb terdapat kata-kata yang mengandung citra pendengaran, seperti سمعي (pendengaranku), نغم (harmoni), dan لحن (melodi), yang menandakan bahwa orang yang mendengarkan ikut merasakan kesedihan yang dialami oleh tokoh 'Aku' dalam lagu ini karena kerinduannya kepada kekasihnya. Selain itu, Aḥmad Rāmī juga menggambarkan kekasih dari tokoh aku dengan keindahan alam dalam lirik lagu Qișsat Hubb, seperti واجتلت زهر الهوى غضاً نديا (kuncup bunga yang merekah), كالبدر يسري (seperti bulan purnama yang menyongsong), dan رقة كالماء يجر (kelembutan seperti air mengalir). Keindahan alam tersebut menunjukkan bahwa kekasih dari tokoh 'Aku' merupakan gadis cantik yang digambarkan melalui bulan purnama, gadis yang lembut yang digambarkan dengan air, serta mencintai kekasihnya ditunjukkan melalui kuncup bunga.

Kata ذكريات yang berarti kenangan juga disebutkan dua kali. Kenangan tersebut digabungkan dengan kalimat ذكريات عبرت أفق خيالي (kenangan berlalu membuka khayalan), ذكريات داعبت فكري (kenangan bertentangan dalam pikiran dan perasaan). Laki-laki dalam lagu tersebut mengingat sebuah kenangan saat ia masih bersama dengan kekasihnya. Kenangan bersama kekasihnya merupakan hal yang dirindukan oleh seorang laki-laki. Jadi, secara makna sintaksis lagu ini menggambarkan kesedihan oleh tokoh 'Aku' (laki-laki) karena rindu terhadap kekasihnya. Padahal kekasihnya sangat sempurna karena ia gadis yang cantik, lembut, dan mencintainya.

\section{Makna Semantik}

Makna semantik dalam semiotik Morris membahas antara tanda dan yang ditandai (Nöth, 1990). Istilah yang disebutkan adalah konotasi dan denotasi. Konotasi merupakan hubungan makna yang tidak langsung, sedangkan denotasi merupakan hubungan makna yang langsung (Zaimar et al., 2014). Pada lirik pertama dalam lagu Qiṣsat Hubb diungkapkan dengan kalimat ذكريات عبرت أفق خيالي (kenangan berlalu membuka khayalan) yang menunjukkan bahwa kenangan tentang kekasihnya sudah lama ia pendam, namun tiba-tiba saja ia mengingatnya pada malam itu sehingga menjadikannya tidak bisa tidur. Kenangan tersebut seolah-olah tidak dapat ia rasakan lagi karena kekasihnya telah pergi. Lalu disebutkan lagi tentang kenangannya, yaitu kenangan bertentangan dalam pikiran dan perasaan yang menandakan bahwa kenangannya pada saat bersama kekasihnnya tidak sesuai dengan pikiran dan perasaannya saat ini. Hal ini menunjukkan bahwa kenangannya sangat indah dan perasaan saat ini tidak seindah kenangannya.

Kata pertama dalam lirik lagu Qișat Hubb adalah ذكريات yang memiliki arti kenangan. Secara tidak langsung, lagu ini menceritakan kenangan tokoh 'Aku' bersama dengan kekasihnya. Penggunaan kata كيف yang diulang sebanyak tujuh kali tidak lagi menandakan sebuah pertanyaan 'bagaimana' namun kata كيف menunjukkan kebingungan oleh tokoh 'Aku'. Tokoh 'Aku' bingung bagaimana cara melupakan kekasihnya, sedangkan kekasihnya masih sangat ia cintai. Ada enam alasan yang membuat tokoh 'Aku' tidak bisa melupakan kekasihnya, yaitu, 


$$
\text { كيف أنساها وقلبي لم يزل يسكن جنبي }
$$

Bagaimana aku melupakannya, bisikan hatiku masih membekas di dalamnya

Kata 'membekas' memiliki arti memberikan kesan yang kuat. Hal ini menunjukkan bahwa rasa cinta tokoh 'Aku' masih ada untuk kekasihnya dan tidak bisa hilang.

$$
\text { كيف أنساها وسمعي لم يذكر دمعي }
$$

Bagaimana aku melupakannya sedangkan aku masih mendengar dan mengingat air mataku

Kata menunjukkan ada kesedihan di dalam kisah cintanya karena tokoh 'Aku' masih mendengar dan mengingat air mata tersebut. Kesedihan yang menimbulkan air mata disebabkan oleh kekasihnya yang meninggalkannya.

Kemudian, pada kata كيف selanjutnya berisi tentang kebingungannya melupakan kenangan bersama kekasihnya. Tokoh 'Aku' mengungkapkan beberapa alasan ia tidak bisa melupakan kenangan seperti وهي في قلبي حنين 'dia di hatiku rindu), وهي في سمعي رنين (dia dalam suara berpadu), dan وهي أحلام حياتي (dia mimpi hidupku). Alasan yang diungkapkan tokoh 'Aku' menunjukkan bahwa meskipun kekasihnya telah pergi, ia tidak bisa melupakannya, karena tokoh 'Aku' sudah yakin bahwa kekasih yang ia cintai merupakan mimpi hidupnya.

Dalam lagu ini juga menggunakan perumpamaan seperti في مقلتيها كان فجرا باسما (fajar lalai dalam menyinari hati yang tidak diketahui) yang berarti bahwa kekasih yang dirindukannya seperti sebuah fajar yang sudah tidak memberikan rasa kasih sayang kepadanya. Fajar secara makna konotasi berarti sebuah cahaya yang ditujukan kepada kekasihnya. Kekasihnya tersebut sudah melupakannya dan tidak memberikan rasa kasih sayang lagi kepada tokoh 'Aku'. Selain itu, pada lagu ini juga mengungkapkan واجتلت زهر الهوى غضاً نديا (jiwaku lupa pada kuncup bunga-bunga mawar muncul merekah). Kuncup bunga berarti cinta yang sedang tumbuh. Hal ini menunjukkan bahwa tokoh 'Aku' tersebut sudah lupa dengan rasa cinta yang sedang tumbuh untuk kekasihnya. Dalam ungkapan lain, كيف لا يشغل فكري طلعة كالبدر يسري (bagaimana pikiranku tidak sibuk melihat bulan purnama menyingsing). Bulan purnama yang dimaksudkan disini adalah kekasih yang memiliki kecantikan yang sempurna seperti bulan purnama. Tokoh 'Aku' tidak bisa melupakan kecantikan kekasihnya. Kata يسري (menyingsing) bermakna kekasihnya yang cantik tersebut sudah meninggalkannya. Oleh karena itu, tokoh 'Aku' merasa bingung. Kemduian, pada lirik selanjutnya disebutkan رقة كالماء يجري فتنة بالحب تغري (kelembutan seperti air mengalir hasutan dengan cinta menggoda), Ini bermakna bahwa kekasihnya adalah orang yang lembut, dan kelembutannya menumbuhkan rasa cinta terhadap tokoh 'Aku'.

Berdasarkan uraian diatas, makna semantik dari lagu Qișat Hubb adalah kebingungan tokoh 'Aku' atas kepergian kekasihnya. Oleh karena itu, bentuk kerinduan yang diceritakan oleh tokoh 'Aku' dalam lagu tersebut adalah berupa kebingungan. 


\section{Makna Pragmatik}

Makna pragmatik dalam pandangan semiotik Morris merupakan makna yang diperoleh dari hubungan antara tanda dengan interpreternya (Nöth, 1990). Interpreter di sini berarti pendengar dari lagu Qișsat Hubb. Pendengar dari lagu ini mengartikan bahwa lagu Qișsat Hubb berisi tentang sebuah kerinduan dari seorang laki-laki terhadap kekasihnya. Kerinduan tersebut sangat mendalam dan tidak akan bisa dituntaskan. Hal ini ditunjukkan dari awal hingga akhir lirik, tokoh 'Aku' menceritakan kenangan bersama kekasihnya, ungkapan kerinduan, ungkapan kesedihan, dan pada akhir lirik كيف أنساها وقلبي لم يزل يسكن جنبي (bagaimana aku melupakannya dan dia masih di hatiku) إنها قصة حبي (inilah kisah cintaku). Pada kedua bait terakhir, menunjukkan bahwa tokoh 'Aku' tetap saja tidak bisa melupakan kekasihnya karena kekasihnya masih sangat ia cintai. Kemudian, dikuatkan dengan kata إن sebagai tawkid atau penguatan, bahwa inilah kisah cintanya. Kisah cinta yang sangat mendalam meskipun kekasihnya tidak bisa ia miliki. Tokoh 'Aku' mengalami penderitaan karena rasa cinta kepada kekasihnya. Cintanya seperti bertepuk sebelah tangan, ia mencintai kekasihnya, namun kekasihnya tidak bisa mencintainya lagi.

Pada lirik pertama ذكريات عبرت أفق خيالي بارقا يلمع في جنح الليالي menunjukkan bahwa kerinduan akan kekasihnya datang secara tiba-tiba. Kerinduan yang digambarkan dalam lagu Qiș̣at Hubb adalah kerinduan yang sangat sehingga membuat seorang laki-laki tersebut bersedih di sepanjang harinya. Penggunaan latar malam menunjukkan makna kehampaan dalam hidupnya. Melalui lagu tersebut, seorang laki-laki menggambarkan kerinduan kekasihnya dengan berbagai ungkapan.

$$
\begin{aligned}
& \text { وأنا أبكي مع اللحن الحزين } \\
& \text { كان فجرا باسما في مقلتيها يوم أشرقت من الغيب عليا } \\
& \text { أنست روحي إلى طلعته واجتلت زهر الهوى غضاً نديا } \\
& \text { فسقيناه ودادا ورعيناه وفاء } \\
& \text { ثم همنا فيه شوقا وقطفناه لقاء } \\
& \text { كيف لا يشغل فكري طلعة كالبدر يسري } \\
& \text { رقة كالماء يجري فتنة بالحب تغري } \\
& \text { تتراك الخالي شجيا }
\end{aligned}
$$

Aku menangis dengan nada sendu

Fajar lalai dalam menyinari hati yang tidak diketahui

Jiwaku lupa pada kuncup bunga-bunga mawar muncul merekah

Untuk menyirami cinta dan menjaga kesetiaan

Lalu penderitaan karena di dalamnya kerinduan dan kita menggoreskan pertemuan

Bagaimana pikiranku tidak sibuk melihat bulan purnama menyingsing

Kelembutan seperti air mengalir hasutan dengan cinta menggoda

Jarak ini membuatku berduka. 
Dari lirik lagu ini menunjukkan bahwa hati laki-laki tersebut tidak tahu milik siapa, karena kekasihnya sudah pergi meninggalkannya. "Kuncup bunga mawar" diartikan sebagai cinta yang masih tumbuh di dalam hatinya. Jika hati selalu mendapatkan kasih sayang dari kekasihnya, maka rasa cintanya akan selalu tumbuh. Namun, laki-laki tersebut tidak mendapatkan rasa cinta karena kekasihnya telah pergi. "Bulan purnama” merupakan kecantikan dari kekasihnya, yang memiliki paras yang cantik. Dengan demikian, dalam lagu Qișat Hubb jika ditinjau dari makna pragmatik, adalah sebuah penderitaan yang disebabkan oleh kerinduan terhadap kekasihnya. Ia selalu menderita sepanjang harinya. Tokoh 'Aku' hampir gila karena mengingat kenangan bersama kekasihnya yang ia rindukan tidak akan kembali karena telah pergi.

\section{Simpulan}

Kerinduan seorang laki-laki dalam lagu Qișsat Hubb jika ditinjau dengan menggunakan semiotik Morris, dapat disimpulkan bahwa (1) makna sintaksis dalam lagu Qișat Hubb adalah kesedihan seorang laki-laki yang ditinggal oleh kekasihnya. Hal ini ditandai dengan adanya beberapa ungkapan kesedihan yang dituliskan dalam lirik lagu tersebut, seperti kata دمعي (air mata), أبكي (aku menangis), شan كيا dang banyak disebutkan dalam lirik lagu tersebut adalah sebagai ungkapan pertanyaan atas kesedihannya bagaimana tokoh 'Aku' hidup tanpa kekasihnya. Kerinduan terhadap kekasihnya menghadirkan kesedihan dalam hidupnya; (2) makna semantik dalam lagu Qissat Hubb adalah kebingungan seorang laki-laki yang ditinggal oleh kekasihnya. Pertanyaan dengan menggunakan كيف menandakan bahwa laki-laki tersebut merasa bingung dan cemas bagaimana ia akan melanjutkan kehidupannya tanpa adanya seorang kekasih. Kerinduan terhadap kekasihnya menghadirkan kebingungan bagi tokoh 'Aku'; dan (3) makna pragmatik dalam lagu Qișat Hubb adalah sebuah kerinduan seorang laki-laki kepada kekasihnya yang menyebakan penderitaan yang hampir membuatnya gila. Lagu tersebut juga bermakna keputusasaan dalam kehidupan seorang lakilaki karena kekasih yang ia rindukan sudah pergi dan tidak akan kembali lagi.

\section{Daftar Rujukan}

Ahmed Rami. (2009, July 20). Egypt State Information Service. Retrieved from https://www.sis.gov.eg/Story/1329

Danielson, V. (1997). The voice of Egypt: Umm Kulthum, Arabic song, and Egyptian society in the twentieth century. Chicago: University of Chicago Press.

Kiram, I. (2019, May 13). Ummi Kulsum: Perempuan pemersatu Arab. Republika. Retrieved from https://www.republika.co.id/berita/pregh6440/ummi-kalsum-perempuan-pemersatu-arab

Lestari, I., Arafah, B., Sahib, H., Makaa, M. (2020). Morris' semiotic in religion perception and conception in Gane of Polinaki traditional wedding ritual in Kulawi ethnic. Language Literacy: Journal of Linguistics, Literature, and Language Teaching, 4(2), 306-315. doi:10.30743/1l.v4i2.3063

Manshur, F. M. (2011). Perkembangan sastra Arab dan teori sastra Islam. Yogyakarta: Pustaka Pelajar.

Nöth, W. (1990). Handbook of semiotics. Bloomington \& Indianapolis: Indiana University Press.

Nöth, W. (2006). Semiotik (A. S. Ibrahim, Terj.). Surabaya: Airlangga University Press. 
Petrilli, S. (2004). From pragmatic philosophy to behavioral semiotics: Charles W. Morris after Charles S. Pierce. Semiotica, 148, 277-315. doi:10.1515/semi.2004.011

Pradopo, R. D. (1987). Pengkajian puisi. Yogyakarta: Gadjah Mada University Press.

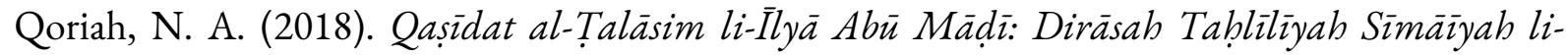
Charles Morris (Skripsi). UIN Sunan Kalijaga, Yogyakarta.

Siswantoro. (2010). Metode penelitian sastra: Analisis struktural puisi. Yogyakarta: Pustaka Pelajar.

Thuraya, T. (2009). Lagu-lagu Ummi Kulsum karya Abmad Mubammad Rami: Analisis struktur teks dan isi (Skripsi). Universitas Indonesia, Depok, Jawa Barat.

Trabaut, J. (1996). Dasar-dasar semiotik (S. Pattinasarany. Terj.). Jakarta: Pusat Pembinaan dan Pengembangan Bahasa Departemen Pendidikan dan Kebudayaan.

Zaimar, O. K. S., \& Harahap, A. K. (2014). Semiotika dalam analisis karya sastra. Depok: Komodo Books. 
Al-Ma'rifah: Jurnal Budaya, Bahasa, dan Sastra Arab, Vol. 18, No. 1, April 2021, 55-66

This page intentionally left blank

66 | http://journal.unj.ac.id/unj/index.php/jba/index 